\title{
Gastroprotective and antioxidant effects of Eremurus spectabilis Bieb. methanol extract and its isolated component isoorientin on indomethacin induced gastric ulcers in rats ${ }^{1}$
}

Esen Sezen Karaoğlan', Abdulmecit Albayrak", Zerrin Kutlu'", Yasin Bayır'v

'MD, Department of Pharmaceutical Botany, Faculty of Pharmacy, Atatürk University, Erzurum, Turkey. Technical procedures, manuscript writing.

"MD, Department of Medical Pharmacology, Faculty of Medicine, Atatürk University, Erzurum, Turkey. Technical procedures.

'"'MD, Department of Biochemistry, Faculty of Pharmacy, Ataturk University, Erzurum, Turkey. Technical procedures.

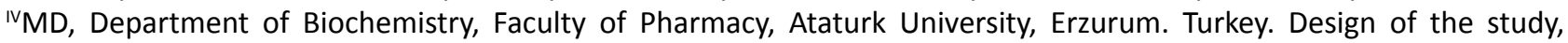
statistical analysis.

\begin{abstract}
Purpose: To investigate the gastroprotective effect of methanol extract of E. spectabilis and its major component isoorientin.

Methods: Effects of isoorientin and methanol extract of E. spectabilis were investigated in indomethacin-induced gastric damage model on rats. Famotidine was used as the standard antiulcer drug. Numerical density of ulcer areas and oxidative status were determined on stomach tissues of rats.

Results: All doses of isoorientin and methanol extract decreased MDA level and increased SOD activity and GSH levels in the stomach tissue of rats. When numerical density of ulcer areas were analized, the $500 \mathrm{mg} / \mathrm{kg}$ dose of methanol extract (84\%) exhibited a similar effect to $20 \mathrm{mg} / \mathrm{kg}$ dose of standart drug famotidine (87\%).

Conclusions: The gastroprotective effects of E. spectabilis and its major constituent isoorientin in rats for the first time. Detailed analyses suggested that potential antioxidant activity of both plant extract and isoorientin mediates the gastroprotective effect.

Key words: Eremurus spectabilis. Stomach Ulcer. Antioxidants. Rats.
\end{abstract}




\section{Introduction}

The peptic ulcer is a deterioration in the gastric or duodenal mucosa down to the submucosa. The various causes of gastric ulcer are stress, trauma, some diseases, helicobacter pylori, use of alcohol and cigarettes, and steroidal and nonsteroidal anti-inflammatory drugs (NSAIDs). Peptic ulcer regarded as a important common gastrointestinal disorder which can affect individuals during their lives ${ }^{1-3}$. The reactive oxygen species (ROS) play an important role in the gastric ulcer formation induced by stress, ethanol and NSAIDs. The inflammation in the gastric tissue induced by indomethacin causes the formation of $\mathrm{ROS}^{4}$. Superoxide dismutase, catalase, glutathione reductase, $\beta$-carotene, glutathione peroxidase, $\beta$-tocopherol, glutathione, vitamins $A$ and $C$ are good antioxidant agents. In addition, these antioxidants are also effective in prevention stomach damage ${ }^{5}$.

The Eremurus genus is a member of Liliaceae family, including about 50 species. E. spectabilis is grown naturally in the eastern regions of Turkey. This plant, locally known as 'Çiris', and its fresh leaves sold and consumed as an edible vegetable in markets ${ }^{6}$.

According to ethnobotanical studies, E. spectabilis is used for the treatment of numerous ailments like scabies, diabetes and intestinal diseases ${ }^{7-9}$. In addition to these, E. spectabilis has also antibacterial and antioxidant activities ${ }^{10,11}$. Carvone, carvacrol, pentane, (E)-caryophyllene, valencene were found to be as main constituents of the essential oil of E. spectabilis ${ }^{12}$. It is reported that inosine, methyl linolenate, chrysophanol, isoorientin, $\beta$-sitosterol and sucrose were also isolated from E. spectabilis ${ }^{13}$. In a previous study, we isolated a high amount of isoorientin from E. spectabilis ${ }^{14}$. Isoorientin is a flavonoid compound in the structure of C-glycosylflavone ${ }^{15}$. Flavonoids are known to have many biological activities. Apart from that, gastroprotective effects of flavonoids are also recorded ${ }^{16}$. Herbal treatment has been used by people for a very long time. E. spectabilis is used in Turkish folk medicine to treat gastrointestinal disorders. The gastroprotective effect of $E$. spectabilis and its major component isoorientin, has not been studied previously. Therefore, the aim of this study was to investigate the effects of $E$. spectabilis methanol extract and its isolated constituent isoorientin in indomethacininduced gastric damage model and to determine the effects of methanol extract and isoorientin on antioxidant parameters in rat stomach tissue.

\section{Methods}

Experiments were performed with male albino Wistar 48 rats weighing 220$280 \mathrm{~g}$. All rats were provided from Ataturk University's Experimental Animal Laboratory at the Medicinal and Experimental Application and Research Centre. When working with experimental animals in this study, national rules were taken as basis and required permission was obtained from Ataturk University's local animal care committee (93722986-000-E.1700331781).

\section{Chemicals}

All of the chemicals required for the study were purchased from Sigma Chemical Co. (Munich, Germany). Indomethacin (Endol $25 \mathrm{mg} ; 25$ cap.) was obtained from DEVA Holding A.S. (Istanbul, Turkey); famotidine (Famodin $20 \mathrm{mg} ; 30 \mathrm{tab}$ ) was obtained from Sandoz Drug Company (Istanbul, Turkey); and thiopental sodium was obtained from IE Ulagay A.S. (Istanbul, Turkey). 


\section{Plant material}

The aerial parts of E. spectabilis were collected from Iğdasor (Erzurum Province, 1920 m, Turkey) in April 2014. A voucher specimen was stored at the Herbarium of Atatürk University, Faculty of Pharmacy (AUEF1189). It was identified by Esen Sezen Karaoğlan.

\section{Previous extraction and isolation studies}

Fresh E. spectabilis leaves were extracted with methanol $(\mathrm{MeOH})$ at $40^{\circ} \mathrm{C}$ after drying and powdeing. The $\mathrm{MeOH}$ extract was filtered and evaporated. The dry $\mathrm{MeOH}$ extract was suspended in water and extracted with n-hexane, dichloromethane $\left(\mathrm{CH}_{2} \mathrm{Cl}_{2}\right)^{\prime}$ ethyl acetate (EtOAc), and n-butanol, respectively. Organic phases were concentrated to dryness under vacuum. Isoorientin was isolated from EtOAc extract via Sephadex $\mathrm{LH}-20$ column eluting with $\mathrm{MeOH}$ and then silica gel column eluting with $\mathrm{CH}_{2} \mathrm{Cl}_{2}$ : $\mathrm{MeOH}$ : $\mathrm{H}_{2} \mathrm{O}$ (90:10:1 $\left.\rightarrow 50: 50: 5\right)$. The structure of isoorientin was elucidated by ${ }^{1} \mathrm{H} N M R,{ }^{13} \mathrm{C}$ NMR, 2D NMR and Q-TOF by Sezen Karaoğlan et al. $^{14}$.

Experimental design of indomethacin-induced ulcer model

Eight experimental groups consisting of six rats were formed:

Group 1: Healthy control;

Group 2: Indomethacin $25 \mathrm{mg} / \mathrm{kg}$ control (IND);

Group 3: Indomethacin $25 \mathrm{mg} / \mathrm{kg}+$ famotidine $20 \mathrm{mg} / \mathrm{kg}$ administered orally (IND+FAM);

Group 4: Indomethacin $25 \mathrm{mg} / \mathrm{kg}$ + isoorientin $25 \mathrm{mg} / \mathrm{kg}$ administered orally (IND+ISO25);

Group 5: Indomethacin $25 \mathrm{mg} / \mathrm{kg}$ + isoorientin $50 \mathrm{mg} / \mathrm{kg}$ administered orally
(IND+ISO50);

Group 6: Indomethacin $25 \mathrm{mg} / \mathrm{kg}+$ isoorientin $100 \mathrm{mg} / \mathrm{kg}$ administered orally (IND+ISO100);

Group 7: Indomethacin $25 \mathrm{mg} / \mathrm{kg}+$ plant extract $250 \mathrm{mg} / \mathrm{kg}$ administered orally (IND+ES250);

Group 8: Indomethacin $25 \mathrm{mg} / \mathrm{kg}+$ plant extract $500 \mathrm{mg} / \mathrm{kg}$ administered orally (IND+ES500).

\section{Ulcer model}

For ulcer model induction in rats previously described indomethacin-ulcer model was used with no modification ${ }^{17,18}$. NSAID induced ulcer model is one of the the most commonly used gastric ulcer models ${ }^{19}$. In this study; the isoorientin groups received $25,50,100 \mathrm{mg} / \mathrm{kg}$ doses and the plant extract groups received 250 and $500 \mathrm{mg} / \mathrm{kg}$ doses and of drugs as a pretreatment by oral gavage, after which the rats were fed anything for 24 hours. Healthy control and indomethacin control groups received $1 \mathrm{ml}$ of saline as vehicle by oral gavage. Then, famotidine (positive control $)^{17}$, isoorientin and plant extract were administered to the corresponding rat groups in the above-mentioned doses by oral gavage. Five minutes after the famotidine, isoorientin and plant extract treatments, a dose of $25 \mathrm{mg} /$ $\mathrm{kg}$ of indomethacin was suspended in isotonic saline and administered by oral gavage to all groups except healthy group. Six hours after the administration of indomethacin, all rats were euthanized by administering intraperitonal thiopental at a dose of $50 \mathrm{mg} / \mathrm{kg}$. The ulcerated areas of the removed stomachs were examined macroscopically. Ulcer areas were evaluated by stereo-investigator, and numerical densities of ulcerated areas were calculated by software, as described below. 


\section{Numerical density (ND)}

Numerical density can be defined as the number of particles in the unit volume. For optical dissector, total number of particles (N) counted should be divided to dissector volume calculate Numerical density of that particles. In our study Numerical Density of Ulcerated area has been calculated by dividing total number of ulcer area to total volume of stomach tissue. In our study, stereological analyses were conducted in a stereology workstation using stereology software (Stereo Investigator version 9.0; MBF Bioscience, Colchester, VT). The numerical ulcer hematoma densities were calculated by the following formula:

Numerical Density (ND): Total Markers Counted x $1000\left(\mu \mathrm{m}^{2}\right) /$ Sampling Grid Area (XY) $\left(\mu \mathrm{m}^{2}\right)$

\section{Biochemical analyses}

Biochemical investigation of stomachs tissues

After the macroscopic analysis, the stomach tissues were stored at $-80^{\circ} \mathrm{C}$. All stomach tissues were milled in liquid nitrogen using a Tissuelyser II grinding jar set (Qiagen, Hilden, Germany). The $50 \mathrm{mg}$ of ground tissues were mixed fully in $1 \mathrm{ml}$ PBS buffer in an Eppendorf tube using the Tissuelyser II, and then centrifuged. Superoxide dismutase (SOD) activity ${ }^{20}$, malondialdehyde (MDA) ${ }^{21}$ and glutathione (GSH) levels ${ }^{22}$ from each samples were measured by repeatedly at room temperature, with an ELISA reader ${ }^{23}$. The average absorbances were calculated. A standard curve was drawn and the equation was obtained from the absorbance of the standards. Linear SOD, GSH, and MDA concentrations were calculated considering this equation. The SOD, GSH, MDA levels were explicated as $\mathrm{U} / \mathrm{mg}$ protein, $\mathrm{nmol} / \mathrm{mg}$ protein. The data are offered as mean \pm standard deviation (SD) per mg protein.

\section{Protein determination}

Protein concentration were carried out by the Lowry method using commercial protein standards (Total protein kit-TP0300- 1 KT; Sigma Chemical Co. (Munich, Germany).

\section{Statistical analyzes}

Statistical Package for the Social Sciences (SPSS) version 20.0 (SPSS Inc., Chicago, IL) software was used for the statistical analysis. The results are presented as means \pm SD. Comparisons between groups were performed using one-way analysis of variance (ANOVA) and the Duncan Multiple Comparison Test which allows inter-comparison of all groups. Significance was accepted at a level of $p<.05$.

\section{Results}

\section{Indomethacin-induced ulcer test}

When we analyzed the numerical densities (ND) of the ulcer hematoma areas, the $500 \mathrm{mg} / \mathrm{kg}$ dose of methanol extract showed a significant $84 \%$ antiulser effect $(p<0.05)$, similar to that of famotidine $87 \%$ $(p<0.05)$. Macroscopical photographs (Figure 1 ) and the ulcer index area of isoorientin (25, $50,100 \mathrm{mg} / \mathrm{kg}$ doses), methanol extract (250, $500 \mathrm{mg} / \mathrm{kg}$ doses), famotidine (20 mg/kg dose) and control groups (Figure 2) are shown in figures. All doses of both extract and isoorientin exerted significant antiulcer effect $(p<0.05)$ as well as famotidine $(p<0.05)$. 

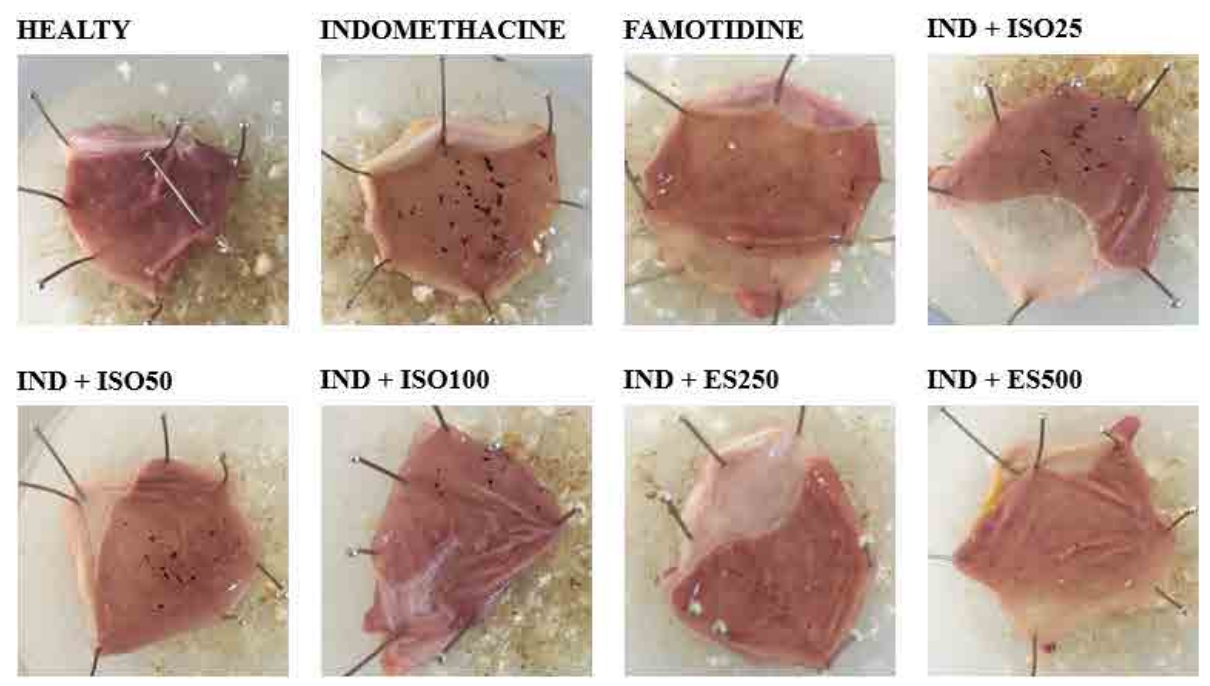

Figure 1 - Sample macroscopical photographs of experimental groups.

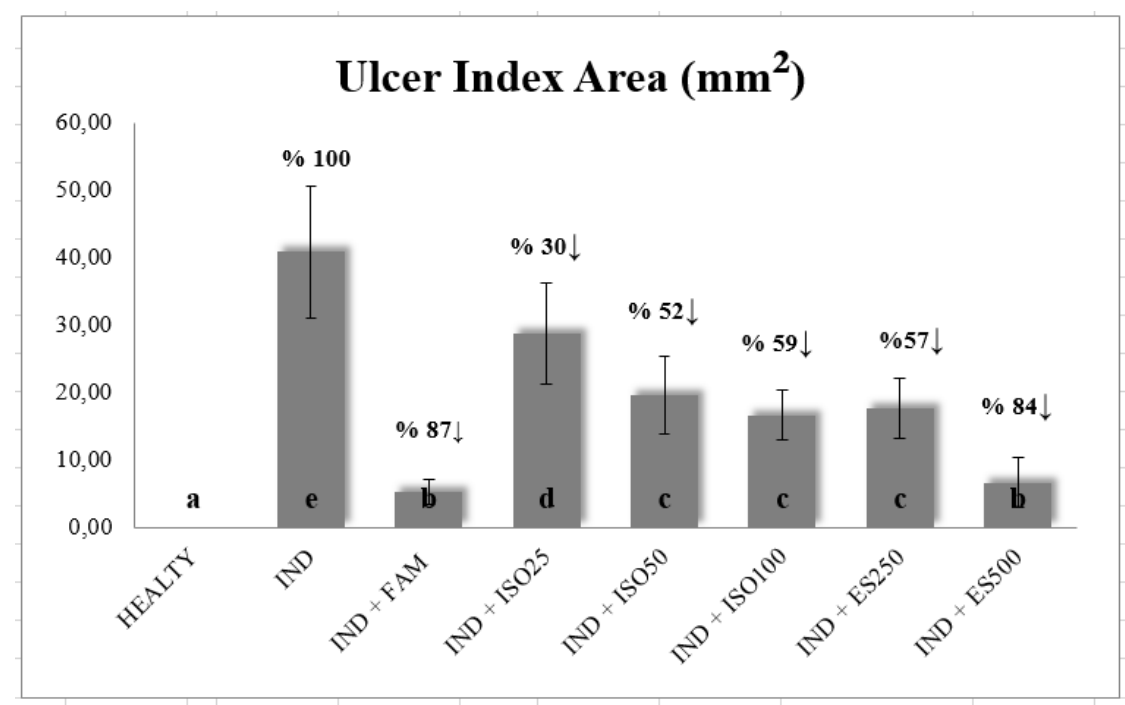

Figure 2 - Ulcer index areas of the groups underwent indomethacin ulcer model. Columns with the same letter are not significantly different; columns with different letters indicate significant differences between the groups according to the Duncan test $(p<0.05)$. Results are means \pm SD. $N 1 / 46$ animals per group. (Numerical density can be defined as the number of particles in the unit volume. For optical dissector, total number of particles $(\mathrm{N})$ counted should be divided to dissector volume calculate Numerical density of that particles. In our study Numerical Density of Ulcerated area has been calculated by dividing total number of ulcer area to total volume of stomach tissue). IND: indomethacine; ISO: isoorientin; ES: extract.

\section{Biochemical analyses}

The all doses of isoorientin and methanol extract significantly $(p<0.05)$ decreased MDA. The most effective decline was observed at the $500 \mathrm{mg} / \mathrm{kg}$ dose of methanol extract dose. All doses of isoorientin and methanol extract significantly increased SOD activity $(p<0.05)$ and GSH levels $(p<0.05)$ in the stomach tissue of rats. the $500 \mathrm{mg} / \mathrm{kg}$ 
dose of methanol extract maximally increased the SOD activity and GSH levels. The SOD activity, GSH and MDA levels of isoorientin (25,
$50,100 \mathrm{mg} / \mathrm{kg}$ doses), methanol extract (250, $500 \mathrm{mg} / \mathrm{kg}$ doses), famotidine (20 mg/kg dose) and control groups (Figures 3 to 5).

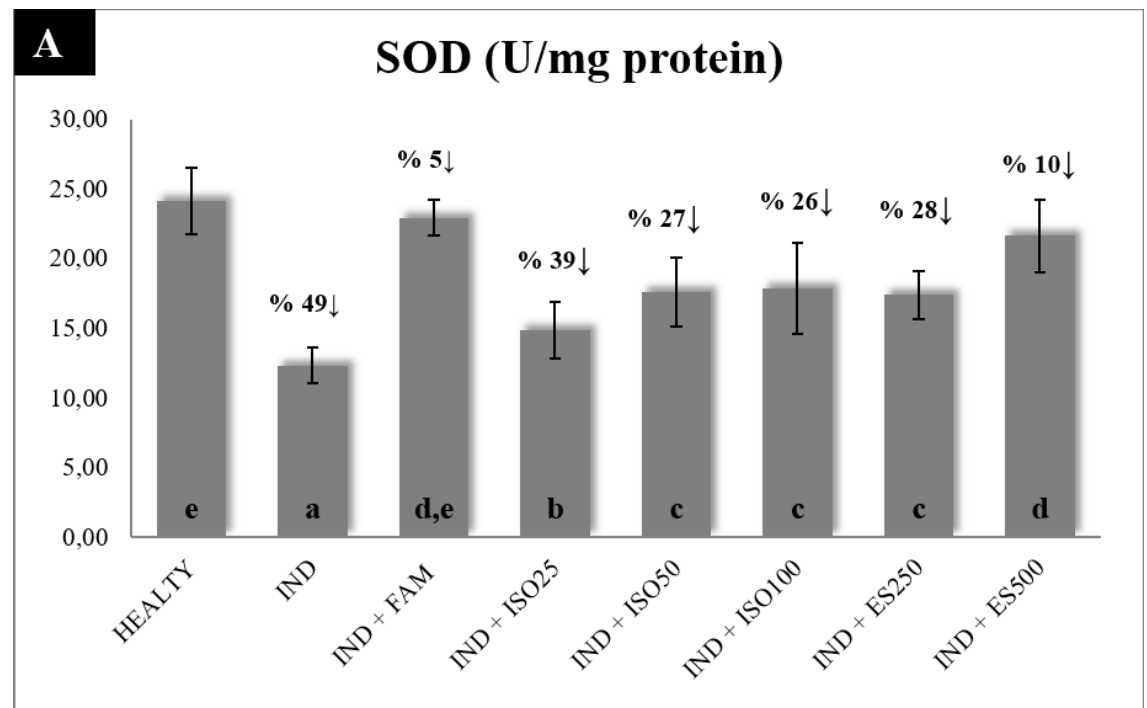

Figure 3 - Stomach tissue SOD activity in groups underwent indomethacin ulcer model. Columns with the same letter are not significantly different; columns with different letters indicate significant differences between the groups according to the Duncan test $(p<0.05)$. Results are means $\pm S D$. N $1 / 46$ animals per group. IND: indomethacine; ISO: isoorientin; ES: extract.

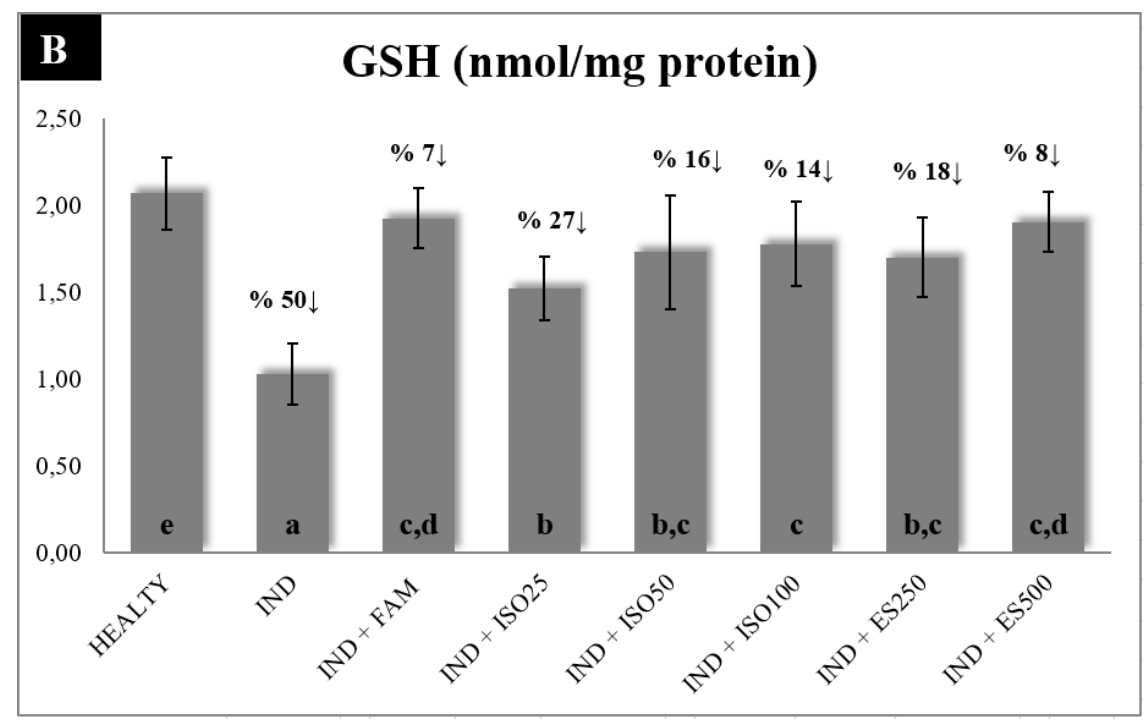

Figure 4 - Stomach tissue GSH level in groups underwent indomethacin ulcer model. Columns with the same letter are not significantly different; columns with different letters indicate significant differences between the groups according to the Duncan test $(p<0.05)$. Results are means $\pm S D$. N $1 / 46$ animals per group. IND: indomethacine; ISO: isoorientin; ES: extract. 


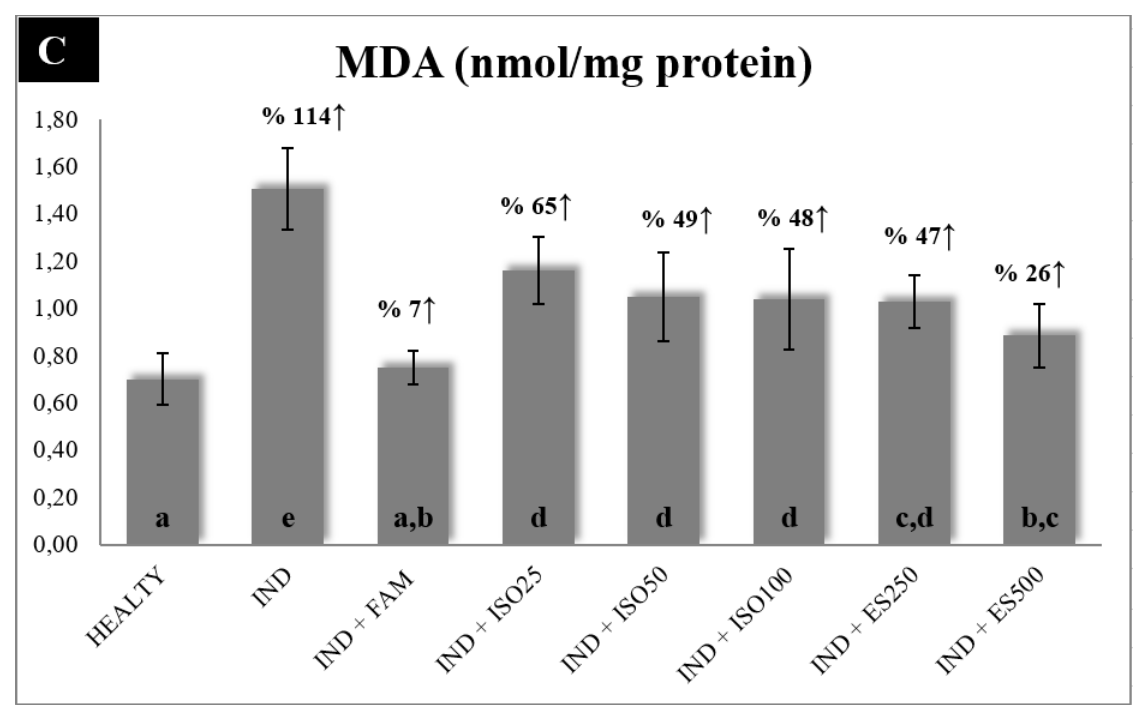

Figure 5 - Stomach tissue MDA level in groups underwent indomethacin ulcer model. Columns with the same letter are not significantly different; columns with different letters indicate significant differences between the groups according to the Duncan test $(p<0.05)$. Results are means \pm SD. N $1 / 46$ animals per group. IND: indomethacine; ISO: isoorientin; ES: extract.

\section{Discussion}

People have been using plants for therapeutic purposes for many years. $E$. spectabilis is locally known as 'Çiris', and is grown naturally in Erzurum, Erzincan, Sivas, Kars, Yozgat, Bitlis, Usak, Agri, Van, Artvin and Ardahan regions in Turkey. This plant is consumed by people as vegetables. Its fresh leaves sold low-priced in markets and contains a high amount of isoorientin. Any toxic effects are not recorded for this plant.

Peptic ulcer is an important disturbance affecting people's quality of life. NSAIDs is one of the important causes of peptic ulceration process $^{1-3}$. It is registered that E. spectabilis is used in gastrointestinal disorders. In a previous study, we isolated a high amount of isoorientin from $E$. spectabilis. Isoorientin is a substance in the flavonoid structure which has many biological activities.

This study investigated the antiulcer activity and the effect on oxidant and antioxidant parameters of different doses isoorientin and methanol extract of $E$. spectabilis in rat stomach tissue. It was observed that the gastroprotective efficacy increased both in the groups isoorientin and in the groups methanol extract depending on the dose. When numerical density of ulcer areas were analized, the $500 \mathrm{mg} / \mathrm{kg}$ dose of methanol extract (84\%) almost exhibited a similar effect to $20 \mathrm{mg} / \mathrm{kg}$ dose of standart drug famotidine (87\%).

The $500 \mathrm{mg} / \mathrm{kg}$ dose of extract showed the highest efficacy, although both extract and isoorientin were observed to be effective when compared to the indomethacin group. In a previous study, ethyl acetate extract of Wilburandia ebracteata showed high anti ulcer effect. This effect was attributed to the substances flavonoid structure, 3',4',5,6,7,8-hexahydroxyflavonol, orientin, luteolin, 6-methoxy-luteolin, vitexin, isoorientin, isovitexin ${ }^{24}$. In our study, we also think that the high efficacy of the plant extract is not due to a single molecule isoorientin, but may be due to the synergistic effect of the different components in it.

We evaluated the effects of isoorientin and methanol extract of $E$. spectabilis on local oxidative stress parameters in the stomach 
tissues of rats as a contributing antiulcer mechanism. Indomethacin dramatically increased stomach MDA content, one of the most widely used parameters as a lipid peroxidation indicator ${ }^{25-29}$, while all doses of isoorientin and methanol extract decreased MDA. In addition, indomethacin caused a significant decrease in stomach antioxidant status, namely decreased SOD activity and GSH levels. Both SOD and GSH are known to be antioxidant agents in inflammatory and ulcerative conditions $s^{30,31}$. In previous studies it was reported that the $E$. spectabilis had significant antioxidant and free radical scavenging activity. In addition, it is known that isoorientin which is a flavonoid, has also highly antioxidant activity ${ }^{32,33}$. In our study, all doses of isoorientin and methanol extract increased SOD activity and GSH levels in the stomach tissue of rats. It has been observed that especially the $500 \mathrm{mg} / \mathrm{kg}$ dose of methanol extract increased these parameters at the approximate value of standart drug famotidine.

It is registered that $E$. spectabilis leaves are used traditionally in gastrointestinal disorders $^{12}$. The results of our work are also supportive of this gastroprotective effect.

\section{Conclusions}

E. spectabilis is a vegetable that is consumed safely among the population. The fresh leaves of this plant are sold at low prices in the markets. It contains high amount isoorientin, has significant gastroprotective effect. Finding new molecules for the pharmaceutical industry is very important, but these studies are costly and time consuming. For this reason, the importance of effective, low-priced and easily accessible standardized plant extracts is increasing. E. spectabilis extract may be a potential anti-ulcer agent in the future. Scientific research in this area needs to be increased.

\section{References}

1. Tarnawski AS, Ahluwalia A. Molecular mechanisms of epithelial regeneration and neovascularization during healing of gastric and esophageal ulcers. Curr Med Chem. 2012;19:16-27. PMID: 22300072.

2. Najm WI. Peptic ulcer disease. Prim Care. 2011;38:383-94. PMID: 21872087.

3. Oppong P, Majumdar D, Atherton J, Bebb J. Helicobacter pylori infection and peptic ulcers. Medicine 2015;43:215-22.

4. Das D, Bandyopadhyay D, Bhattacharjee M, Banerjee RK. Hydroxyl radical is the major cousative factor in stressinduced gastric ulceration. Free Radical Biol Med. 1997;23:8-18. PMID: 9165292.

5. Mates JM, Perez-Gomez C, Nudez de Castro I. Antioxidant enzymes and human diseases. Clin Biochem. 1999;32:595-603. PMID: 10638941.

6. Tuzlacı E. Çiriş plants of Turkey. J Pharm Univ Mar. 1985;1:69-89.

7. Karaman S, Kocabaş YZ. Traditional medicinal plants of K. Maraş (Turkey). Sciences. 2001;1:125-8.

8. Arıtuluk ZC, Ezer N. Halk arasında Diyabete Karşı Kullanılan Bitkiler (Türkiye)-II. Hacettepe Üniv Ecz Fak Derg. 2012;32:179208.

9. Korkmaz M, Karakuş S. Traditional uses of medicinal plants of Üzümlü District, Erzincan. Turkey. Pak J Bot. 2015;47:125-34. PMID: 17714898.

10.Kanaani S, Sani AM. Chemical composition of essential oils and in vitro antibacterial activity of methanolic extract of Sonchus arvensis and Eremurus spectabilis against food-borne pathogenic bacteria. J Essent Oil Bear. 2015;18:1093-9.

11. Taskin T, Bitis L, Birteksöz S. Antioxidant and antimicrobial activities of different extracts from Eremurus spectabilis leaves. Spatula DD. 2012;2:213-7.

12.Karaman K, Polat B, Ozturk I, Sagdic O, Ozdemir C. Volatile compounds and bioactivity of Eremurus spectabilis (Ciris), a Turkish Wild Edible Vegetable. J Med Food. 2011;14:1238-43. PMID: 21548806.

13. Karakaya L, Akgül Y, Nalbantsoy A. Chemical constituents and in vitro biological activities of Eremurus spectabilis leaves. Nat Prod Res. 2017;20:1-6. PMID: 28278652. 
14.Sezen Karaoğlan E, Gündoğdu G, Seçme $M$, Senol O, Demirkaya Miloğlu F, Dodurga $Y$, Tüfekçi AR. Eremurus spectabilis, rich source of isoorientin: isolation, quantification and anti-cancer activity on SH-SY5Y neuroblastoma cells. Curr Pharmaceutical Analysis. 2018;13. [Epub ahead of print]. doi: $10.2174 / 15734129136661708221625$ 27.

15.Afifi FU, Khalil E, Abdalla S. Effect of isoorientin isolated from Arum palaestinum on uterine smooth muscle of rats and guinea pigs. J Ethnopharmacol. 1999;65:173-7. PMID: 10465658.

16.Zayachkivska OS, Konturek SJ, Drozdowicz D, Konturek PC, Brzozowski T, Ghegotsky MR. Gastroprotective effects of flavonoids in plant extracts. J Physiol Pharmacol. 2005;56:219-31.

17. Halici Z, Polat B, Cadirci E, Topcu A, Karakus $E$, Kose D, Albayrak A, Bayir Y. Inhibiting renin angiotensin system in rate limiting step by aliskiren as a new approach for preventing indomethacin induced gastric ulcers. Chem Biol Interact. 2016;25;258:266-75.

18.Atalay F, Odabasoglu F, Halici M, Cakir A, Cadirci E, Aslan A, Aydin Berktas O, Kazaz C. Gastroprotective and antioxidant effects of Lobaria pulmonaria and its metabolite rhizonyl alcohol on indomethacininduced gastric ulcer. Chem Biodivers. 2015;12(11):1756-67.

19.Suleyman H, Albayrak A, Bilici M, Cadirci $E$, Halici Z. Different mechanisms in formation and prevention of indomethacininduced gastric ulcers. Inflammation. 2010;33(4):224-34.

20.Sun Y,. Oberley LW. Li YA. A simple method for clinical assay of superoxide dismutase. Clin Chem. 1988;34:497-500. PMID: 3349599.

21.Ohkawa H, Ohishi N, Yagi K. Assay for lipid peroxides in animal tissues by thiobarbituric acid reaction. Anal Biochem 1979;95:351-8. PMID: 36810.

22.Sedlak J, Lindsay RH. Estimation of total, protein-bound, and nonprotein sulfhydryl groups in tissue with Ellman's reagent. Anal Biochem. 1968;25:192-205. PMID: 4973948.

23.Bayir Y, Karagoz Y, Karakus E, Albayrak A, Sengul O, Can I, Yayla N, Kuskun U, Keles MS. Nigella sativa reduces tissue damage in rat ovaries subjected to torsion and detorsion: oxidative stress, proinflammatory response and histopathological evaluation. Gynecol Obstet Invest. 2012;74:41-9. PMID: 22441173.

24.Coelho RG, Gonzalez FG, Sannomiya M, Di Stasi LC, Vilegasa W. Gastric anti-ulcer activity of leaf fractions obtained of polar extract from Wilbrandia ebracteata in mice. Nat Prod Res. 2009;23:51-9. PMID: 18989825.

25.Suleyman $H$, Cadirci E, Albayrak A, Polat B, Halici Z, Koc F, Hacimuftuoglu A, Bayir Y. Comparative study on the gastroprotective potential of some antidepressants in indomethacin-induced ulcer in rats. ChemBiol Interact. 2009;180:318-24. PMID: 19497431.

26.Dengiz GO, Odabasoglu F, Halici Z, Cadirci E, Suleyman H. Gastroprotective and antioxidant effects of montelukast on indomethacin-induced gastric ulcer in rats. J Pharmacol Sci. 2007;105:94-102. PMID: 17895592.

27.Altinbas B, Yilmaz MS, Savci V, Jochem $\mathrm{J}$, Yalcin M. Centrally injected histamine increases posterior hypothalamic acetylcholine release in hemorrhagehypotensive rats. Aut Neurosci Basic Clin. 2015;187:63-9. PMID: 25468497.

28.Jochem J, Zwirska-Korczala K, Sowa P, Berdowska A. Interactions between the histaminergic and angiotensinergic systems in the central cardiovascular regulation in rats. Inflam Res. 2006;55:69-70. PMID: 16547806.

29.Cadirci E, Suleyman H, Aksoy H, Halici Z, Ozgen U, Koc A, Ozturk N. Effects of Onosma armeniacum root extract on ethanolinduced oxidative stress in stomach tissue of rats. Chem Biol Interact. 2007;170:40-8. PMID: 17681286.

30.Kaplan KA, Odabasoglu F, Halici Z, Halici M, Cadirci E, Atalay F, Aydin O, Cakir A. AlphaLipoic acid protects against indomethacininduced gastric oxidative toxicity by modulating antioxidant system. J Food Sci. 2012;77:224-30. PMID: 23057764.

31.Odabasoglu F, Halici Z, Cakir A, Halici M, Aygun $H$, Suleyman $H$, Cadirci $E$, Atalay $F$. Beneficial effects of vegetable oils (corn, olive and sunflower oils) and alphatocopherol on anti-inflammatory and gastrointestinal profiles of indomethacin 
in rats. Eur J Pharmacol. 2008;591:300-6. PMID: 18621042.

32.Tosun $M$, Ercişli $E$, Ozer $H$, Turan $M$, Polat T, Ozturk E, Padem H, Kilicgun H. Chemical composition and antioxidant activity of foxtail lily (Eremurus spectabilis). Acta Sci Pol Hortorum Cultus. 2012;11:145-53.
PMID: 25649168.

33 Joshi KR, Devkota HP, Nakamura T, Watanabe T, Yahara S. Chemical constituents and their DPPH radical scavenging activity of nepalese crude drug Begonia picta. Rec Nat Prod. 2015;9:446-50.

\section{Correspondence:}

Esen Sezen Karaoğlan

Department of Pharmaceutical Botany, Faculty of Pharmacy

Atatürk University, Erzurum Turkey

Phone: 05436592903

Fax: +90 (442) 2315201

esen.karaoglan@atauni.edu.tr

Received: Mar 10, 2018

Review: May 08, 2018

Accepted: June 12, 2018
Conflict of interest: none

Financial source: none
${ }^{1}$ Research performed at Department of Pharmaceutical Botany, Faculty of Pharmacy, Department of Medical Pharmacology, Faculty of Medicine and Medical Experimental Application and Research Center, Atatürk University, Erzurum, Turkey. 